\title{
Learning design som systematisk alternativ til one-hit wonders \\ - implementering af educational it i de våde fag på Aarhus Universitet
}

\section{Mikkel Godsk}

Teamleder og doctoral researcher

ST Learning Lab, Aarhus Universitet

Institute of Educational Technology, Open University godsk@stll.au.dk

\section{Janne Saltoft Hansen}

E-læringskonsulent og Blackboardprojektleder

Center for Sundhedsvidenskabelige Uddannelser, Aarhus Universitet jsh@cesu.au.dk
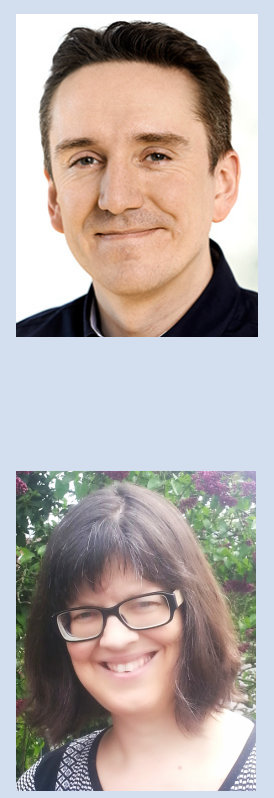
Mikkel er teamleder og e-læringskonsulent ved ST Learning Lab, Faculty of Science and Technology, Aarhus Universitet samt doctoral researcher i learning design ved Institute of Educational Technology, The Open University (UK).

Janne er e-læringskonsulent ved Center for Sundhedsvidenskabelige Uddannelser og projektleder for Blackboard-implementeringen på Faculty of Health, Aarhus Universitet. 


\section{Abstract}

Aarhus Universitet (AU) vedtog i 2011 en ambitiøs politik for educational it med en række indsatsområder, hvoraf særligt anskaffelsen og implementeringen af en fælles e-læringsplatform, uddannelse af universitetets undervisere samt udvikling af undervisningen er af højeste prioritet (Aarhus Universitet, 2011). Pga. begrænsede midler har der imidlertid været behov for en ekstraordinær systematisk og effektiv måde at håndtere implementerings- og udviklingsarbejdet på. Dette bevirkede, at Faculty of Science and Technology (ST) i 2013 udviklede et learning design-framework, STREAM (Godsk, 2013), til at guide transformeringen af kurser og som et omdrejningspunkt for uddannelse af undervisere på fakultetets adjunktpædagogikum. I 2015 blev STREAM endvidere adopteret af Faculty of Health (HE) og her yderligere operationaliseret til et såkaldt toolkit vha. Dee Finks castle-top diagram for således at muliggøre eksplicit design af sammenhængende undervisningsforløb (Conole \& Fill, 2005; Fink, 2013). En operationalisering, der betød, at learning designtilgangen også kunne benyttes til at pædagogisk kvalificere implementeringen og ibrugtagningen af universitetets nye elæringsplatform, Blackboard Learn. I artiklen beskriver vi vores learning design-framework, STREAM, de dertilhørende toolkits ved de våde fag (dvs. fag på HE og ST ved AU), samt tre cases omkring hvorledes framework er anvendt til såvel uddannelse af undervisere og transformering af kurser. Ydermere reflekteres der over learning design-tilgangen som metode til systematisk og effektiv implementering og udvikling af educational it ved et universitet.

\section{English abstract}

In 2011 an ambitious policy for educational IT was issued at Aarhus University (AU). The policy includes a number of focus areas of which particularly the acquisition and implementation of a common e-learning platform, training of educators, and the development of teaching are of the highest priority (Aarhus Universitet, 2011). Due to limited funds there has been a need for an extraordinary systematic and effective way to manage the work of implementation and development. This meant that Faculty of Science and Technology (ST) in 2013 developed a learning design framework, STREAM (Godsk, 2013), to guide the transformation of modules and as a focal point in the faculty's teacher training programme. In 2015 STREAM was adopted by the Faculty of Health (HE) and further operationalised to a so-called toolkit using Dee Fink's castle-top diagram, thus allowing the educators to make explicit designs of coherent teaching (Conole \& Fill, 2005; Fink, 2013). This operationalisation meant that the learning design approach could also be used to pedagogically qualify the implementation and deployment of the university's new e-learning platform, Blackboard Learn. In the article we describe our learning design 
framework, STREAM, the associated toolkits at HE and ST, and three cases of how the framework is used for both teacher training and transformation of modules. Furthermore, we reflect on the learning design approach as a method for systematic and effective implementation and development of educational IT at a university.

\section{Baggrund og udfordring}

Det aktuelle politiske krav om både besparelser på uddannelsesområdet, stigende optag og bedre fremdrift i uddannelserne på samme tid (Finansministeriet, 2016; Uddannelses- og forskningsministeriet, 2014) har bevirket, at der er opstået et ekstraordinært behov for en systematisk, økonomisk og administrativ bæredygtig samt skalérbar tilgang til udvikling af undervisning. Samtidig er Aarhus Universitet i disse år i gang med en modernisering af undervisningen med et særligt fokus på brug af teknologi. Det bagvedliggende koncept for moderniseringen er betegnet educational $i t$, hvoraf de følgende tre indsatser er helt centrale:

- "anskaffelse, drift og udvikling af én fælles e-læringsplatform for educational it",

- "opkvalificering af undervisere ... både teknisk og pædagogisk" i educational it, samt

- "udvikling af undervisningsforløb" og "nytænkning af undervisningen" vha. educational it (Aarhus Universitet, 2011; pp. 67-68).

Målsætningen er, at $60 \%$ af universitets undervisere skal have tilbudt "nytænkning" af deres undervisning pr. 1. februar 2015 (Aarhus Universitet, 2011). Pga. forsinkelser i anskaffelse og implementering af elæringsplatformen, som i denne sammenhæng refererer til universitetets learning management system (LMS) Blackboard Learn, er denne dato imidlertid blevet udskudt godt halvandet år. Med undtagelse af den tekniske implementering af ny e-læringsplatform, der varetages af itafdelingen og en særlig projektgruppe, ligger ansvaret for de øvrige indsatser hos de fire fakulteter og deres pædagogiske centre.

Samlet set står universitetet over for et velkendt dilemma, som bl.a. tidligere Open University-rektor John Daniel har omtalt som "the iron triangle" (Daniel et al., 2009). Dilemmaet er kendetegnet ved, at undervisningskvalitet, studenteroptag og undervisningsomkostninger følges ad ved traditionel konfrontationsundervisning, og hvis man fx vil øge optag eller højne kvaliteten, vil det være med højere omkostninger til følge. For at bryde the iron triangle, dvs. øge optaget og/eller kvaliteten uden samtidig at øge omkostningerne, er det nødvendigt at tage et opgør med de traditionelle undervisningsformer baseret på primært konfrontationsundervisning ved eksempelvis at benytte teknologi i undervisningen (Daniel et al., 2009). Introduktionen af teknologi i 
undervisningen kræver imidlertid også ressourcer og er ofte præget af enten lone ranger- eller boutique course development-tilgangene (Bates, 2005; pp. 164-165). Lone ranger-tilgangen er kendetegnet ved entusiastiske undervisere, der udvikler deres kurser og materialer individuelt og efter bedste evne, mens boutique course developmenttilgangen er kendetegnet ved undervisere, der modtager individuel, on demand-support til transformeringen af deres kursus af fx en pædagogisk konsulent. Disse tilgange er imidlertid præget af enten høje omkostninger pga. behovet for den individuelle pædagogiske support, begrænset skalérbarhed pga. den person- eller kursusspecifikke indsats eller varierende pædagogisk kvalitet pga. underviserens manglende viden om pædagogisk teori og metode (Bates, 2005), hvilket gør det svært at bryde the iron triangle. Ydermere er der en risiko for one-hit wonder-fænomenet, hvor en vellykket transformering af et kursus er enkeltstående og uden videre afsmittende eller varig effekt på den øvrige undervisning. For at undgå disse barrierer i forbindelse med implementeringen af educational it på AU er valget faldet på 'learning design'-tilgangen som et systematisk alternativ. Den pædagogiske teori er i denne tilgang operationaliseret vha. modeller og principper, som underviserne selv, på fleksibel vis, kan benytte til at guide transformeringen af deres undervisning og til at dele erfaringerne fra deres praksis (Cross \& Conole, 2009). Det er således potentielt muligt gennem brug af learning design både at skalere og kvalificere teknologi-indsatsen baseret på pædagogisk teori med begrænsede omkostninger til følge.

\section{Learning design og STREAM}

Learning design er kendetegnet ved en operationalisering af pædagogisk teori vha. modeller, materialer og/eller designprincipper. Undervisere er tiltænkt en aktiv rolle som designer af undervisningen med de pågældende modeller, og der er et særligt fokus på de studerendes læring. Learning designs kan understøttes af mere eller mindre detaljerede pædagogiske modeller, hvor man i den ene ende at spekteret finder de såkaldte frameworks, der tilbyder en åben og fleksibel ramme for transformering af undervisning, og fordelt over resten af spektret finder de mere detaljerede toolkits og wizards, der inkluderer skabeloner til udvikling af kursusspecifikke designs samt værktøjer til produktion af materialer, og som gerne er suppleret med modeller og materialer til at repræsentere, genbruge og dele designs (Agostinho, 2006; Conole \& Fill, 2005; Conole, 2013; Cross \& Conole, 2009; Koper \& Tattersall, 2010; Mor \& Craft, 2012; Mor \& Winters, 2007; Oliver \& Conole, 2000; Sims, 2006). Tilgangen er således set som en potentiel effektiv og skalérbar måde til at implementere teknologi i undervisningen pga. en minimering af behovet for pædagogiske konsulenter, designere, it-udviklere o lign., da underviseren selv står for transformeringen, samt genbrugen af materialer og designs (Britain, 2004; Conole \& Fill, 2005; Cross et al., 2008; Oliver \& Conole, 2002). Samtidig er 
learning design en mulig fælles referenceramme eller en række såkaldte boundary objects (Star, 1989; Wenger, 2000), der potentielt kan øge udbyttet og kvaliteten af samarbejdet mellem de pædagogiske miljøer, hvor de undervisningspædagogiske teorier skabes og de faglige miljøer, hvor konkrete undervisningsforløb udvikles og finder sted. En fælles referenceramme kan danne grundlag for systematisk undervisningsudvikling i det direkte samarbejde mellem pædagogiske og faglige miljøer fx på pædagogiske kurser eller i pilotprojekter, men også indirekte, da ildsjælen fra fagmiljøet, der før var blevet lone ranger, gives et sprog og nogle redskaber at bringe med tilbage i sit faglige miljø. Et vigtigt element i learning design bliver således det pædagogiske framework og det eventuelt dertilhørende toolkit (inkl. dets iboende sprog og supplerende materialer), som skal passe til den pågældende faglighed og undervisningspraksis.

Erfaringerne fra en række projekter og tiltag med aktiv læring (Bonwell \& Eison, 1991), Flipped Classroom (FC) (Mazur \& Hilborn, 1997), Peer Instruction (PI) vha. clickers, PeerWise (Denny et al., 2008a; 2008b) og Justin-Time Teaching (JiTT) (Novak et al., 1999; Simkins \& Maier, 2010) på ST viste, at det er nyttigt med en pædagogisk velfunderet model til at guide udviklingen og implementeringen. Derfor, baseret på de gode erfaringer med JiTT til at studenter-centrere undervisningen og forbedre feedback vha. out-of-class-aktiviteter og in-class-opfølgning, aktiv læring som ramme for at få de studerende til at arbejde med pensum, FC som model for kvalificering af out-of-class-forberedelsen og anvendelsen af forelæsninger samt PI som princip for øget samarbejde mellem de studerende og til feedback, blev STREAM udviklet i 2013. STREAM er et akronym for "Science and Technology Rethinking education through Educational IT towards Augmentation and Modification". "Science and Technology" henviser til det fagområde det oprindeligt er tiltænkt, "rethinking" er educational it-politikkens begreb for nytænkning/udvikling og "augmentation" samt "modification" refererer til to niveauer for teknologibrug i undervisningen jf. Puenteduras SAMR-model (Puentedura, 2010).

STREAM er et såkaldt framework, hvilket i praksis vil sige, at den tilbyder en fleksibel ramme for transformering af undervisningen til blended og online læring (Conole \& Fill, 2005). STREAM skal således hverken ses om en detaljeret drejebog for transformering eller udelukkende som et pædagogisk koncept, men ikonerne vist i figur 1 refererer til mulige materialetyper og værktøjer (i Blackboard og andre systemer), som kan anvendes til at understøtte den pågældende aktivitet, hvorved figur 1 også kan anvendes som toolkit. 


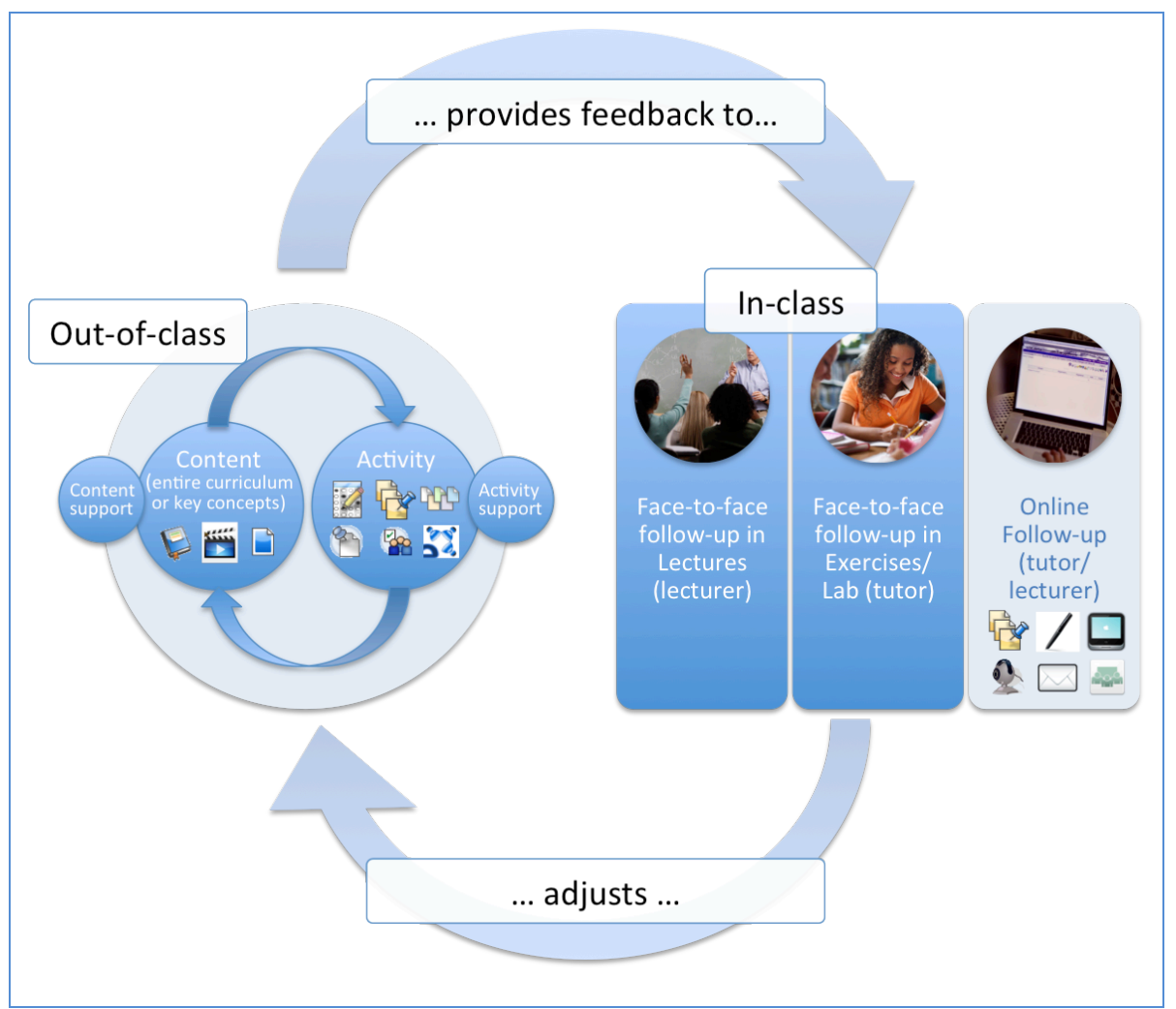

Figur 1. STREAM (Godsk, 2013).

I praksis vil det sige, at man $\mathrm{fx}$ kan benytte STREAM til at strukturere sin undervisning med de to loops den indeholder. Et out-of-class-loop forud for hver undervisningsgang bestående af en række såkaldte content-elementer, fx artikler, kapitler i lærebogen, videoer og andre pensumbærende materialer, der for hvert element efterfølges af en aktivitet. Contentelementerne kan være af varierende omfang, men ofte er det værd at inddele out-of-class-loopet i flere, mindre bidder, hvor aktivitet kan skabes vha. en multiple choice-quiz, diskussionsaktivitet, refleksionsøvelse el.lign. De studerendes deltagelse i out-of-class-aktiviteterne genererer information om de studerendes niveau og eventuelle problemer, som underviseren herefter kan følge op på in-class i en forelæsning, i $\emptyset$ velsestimer eller online via fx video eller e-mail. Erfaringerne fra in-classundervisningen eller den online opfølgning kan igen anvendes til at justere den efterfølgende undervisningsgangs out-of-class-indhold og -aktiviteter.

STREAM er yderligere konkretiseret til to toolkits: ét på ST og ét på HE. Toolkittet på ST består i STREAM-initiativet med en række materialer samt pædagogiske og tekniske services. De pædagogiske services består af individuel vejledning af undervisere ift. transformering af undervisning vha. STREAM ved fakultetets pædagogiske konsulenter, en række online ressourcer, der introducerer til STREAM samt assistance til evaluering og vidensdeling af effekt. De tekniske services varetages af fakultetets medieproduktionsenhed, Science Media Lab (SML), og består af tre gør-detselv-webcaststudier (figur 2) samt support til opsætning af læringsstier, 
online aktiviteter m.m. i Blackboard i overensstemmelse med STREAM. I webcaststudierne kan underviserne selv låse sig ind og med få klik producere 2-kanals-undervisningsvideoer vha. en interaktiv skærm, en præsentations-PC og et kamera. Videoerne gøres automatisk tilgængelige på nettet via LifeSize Video Center (LifeSize, 2016) og kan efterfølgende indlejres på Blackboard.

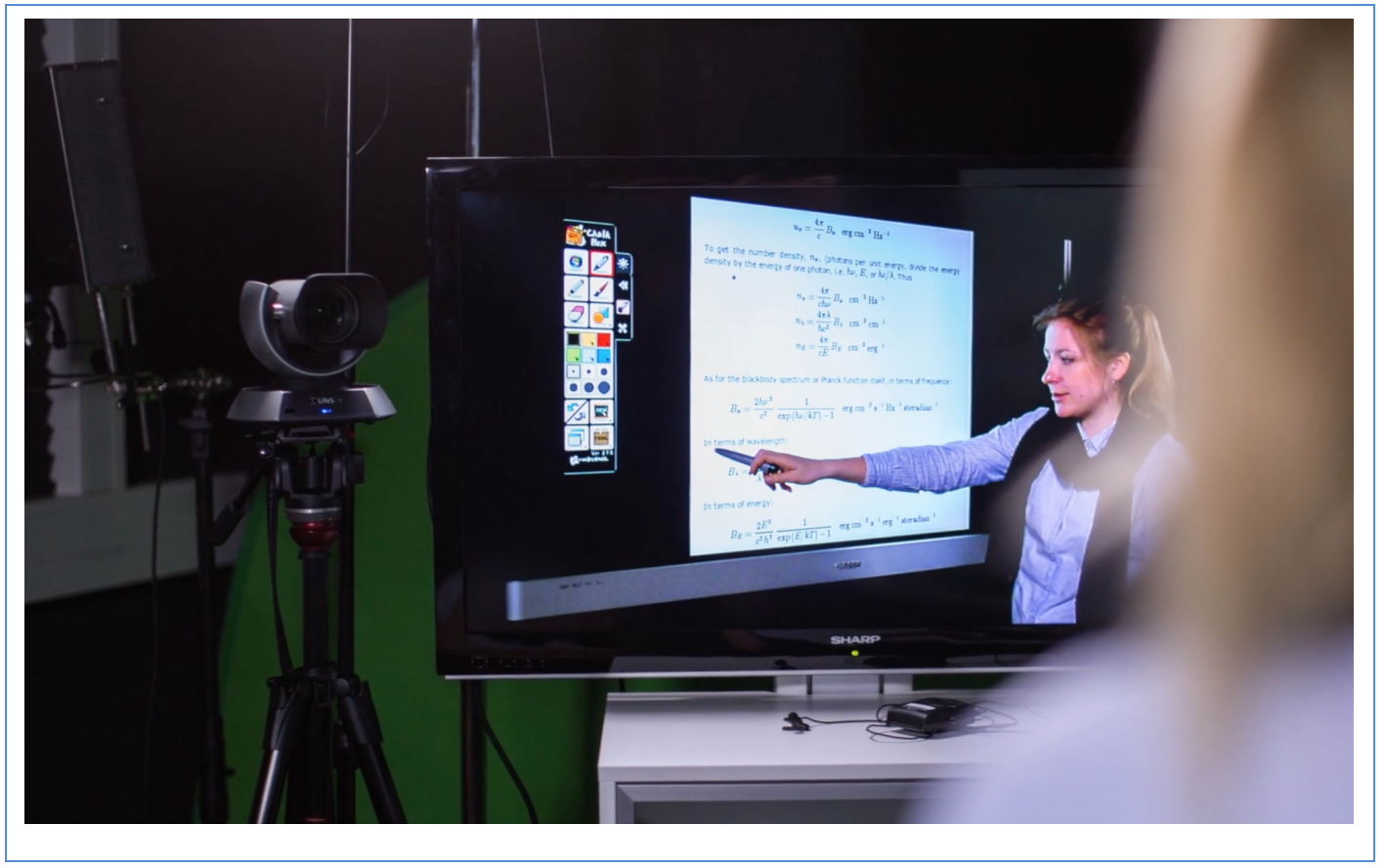

Figur 2. Webcaststudie 1, der fungerer som gør-det-selvproduktionsløsning til webcasts på ST.

Forholdene på HE er anderledes end på ST på områder, der er centrale for undervisningsudvikling. På HE varetages meget undervisning af deltidsansatte undervisere med anvendt praktisk erfaring, hvis primære job er professioner som fx læge eller tandlæge. Da mange udelukkende underviser i eget speciale, betyder det, at undervisningen varetages af en mængde forskellige undervisere, og på visse fag er der tilknyttet op mod hundrede forskellige undervisere på et enkelt kursus. På de kurser, hvor antallet af undervisere er stort, vil det være en udfordring at skabe sammenhæng i undervisningen. På HE er det derfor vigtigt, at en central model i et learning design-toolkittet tager højde for denne sammenhæng og er direkte applicérbar for de undervisere, der kun har meget begrænset tid til forberedelse.

HE har derfor valgt at udvikle et toolkit, som bl.a. Indeholder en central learning design-model, der bygger på det grundlæggende begrebsapparat fra STREAM for på denne måde at bibeholde et fælles sprog og en fælles referenceramme og samtidig imødekomme en visualisering af undervisningssammenhænge og et operationaliseret design tilpasset målgrupper og lokale forhold. 
STREAMs cirkulære udformning illustrerer undervisningsforløbets iterative karakter og i den praktiske planlægning af et undervisningsforløb gennemløbes STREAM flere gange. Ved en operationalisering er der derfor behov for, at STREAMs ydre loop udfoldes til det antal, der matcher det specifikke undervisningsforløb eller den del af undervisningsforløbet, man $\emptyset$ nsker at arbejde med. Herved kan en underviser skitsere sit design direkte i modellen, samt se sin egen undervisning eller dele af denne i sammenhæng med det resterende undervisningsforløb,

Som inspiration til videreudvikling af STREAMs operationelle dimension er Dee Finks castle-top diagram (Fink, 2013) indarbejdet:

\section{"Laying out the combination of inclass and out-of-class activities in a "castle-top" diagram allows the teacher to sense how dynamic the teaching strategy is." \\ (Dee Fink, 2005; p. 5)}

På baggrund af Godsks STREAM-framework og Dee Finks Caste-top diagram er der på HE's pædagogiske center udviklet en model til undervisningsplanlægning som en del af fakultetets learning design-toolkit

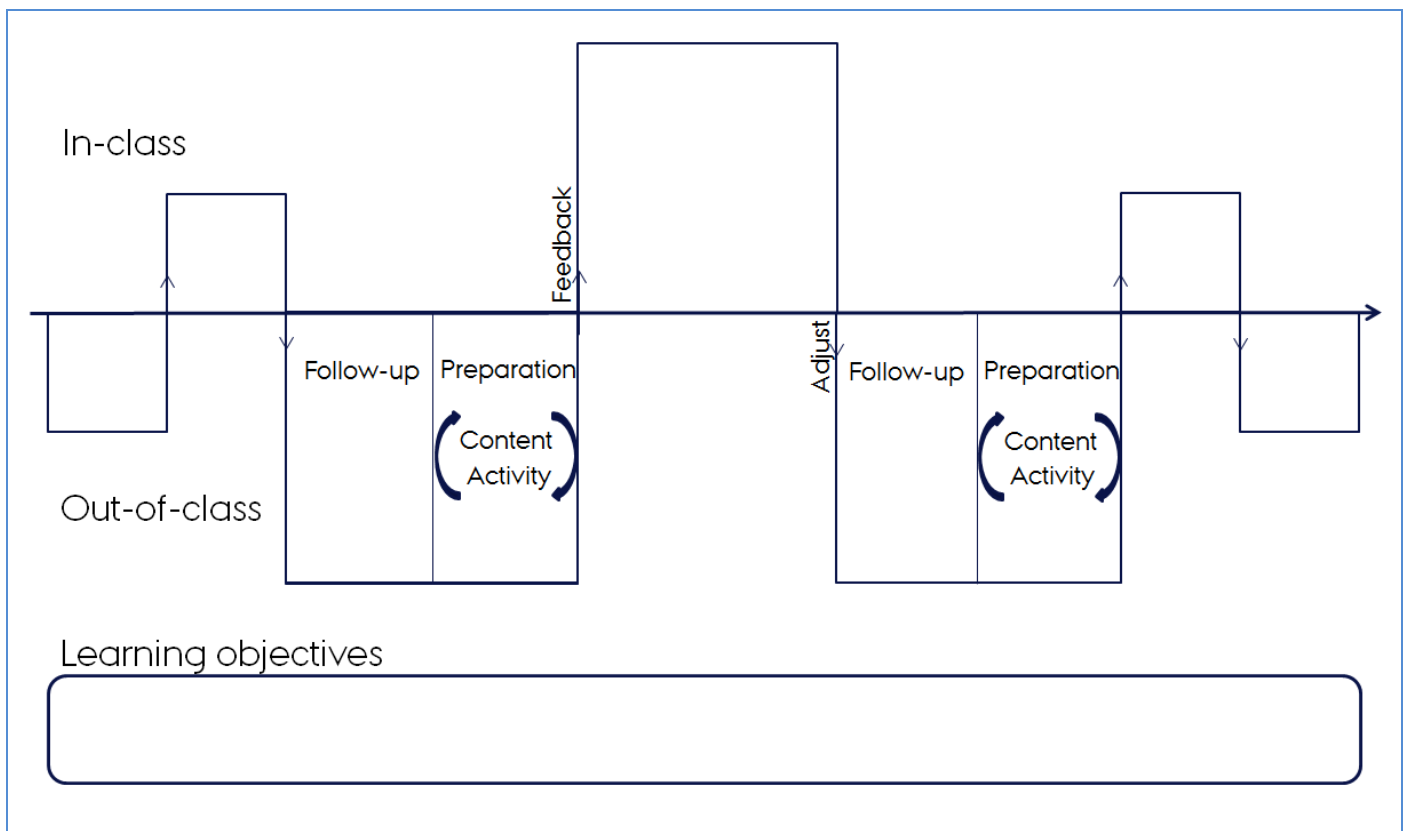

Figur 3. Health Learning Design Model, som er udgør den centrale del af Health Learning Design Toolkit

Modellens ydre struktur er castle-top diagrammets med in-class og out-ofclass-aktiviteter henholdsvis oven for og neden for en tidslinje. Hermed bliver det muligt for underviserne at overskue hele undervisningsforløbet på en gang eller arbejde med udvalgte dele uden at miste fokus på relationen til tidligere og efterfølgende aktiviteter i undervisningsforløbet. Den røde tråd igennem forløbet er illustreret ved hjælp af pile, der følger 
castle-top strukturen. På disse pile er vedhæftet labels fra STREAMs ydre loop, således at det angives, at out-of-class aktiviteter giver feedback til underviserne om de studerendes aktivitet og eventuelle udfordringer, og at underviseren kan justere out-of-class-aktiviteter i forhold til konfrontationstimernes aktuelle begivenheder.

For yderligere at illustrere sammenhæng i undervisningsforløbet er out-ofclass-feltet delt i et rum for opfølgning og et rum for forberedelse. På denne måde skærpes opmærksomheden på, hvordan den enkelte del i undervisningsforløbet er sammenhængende med resten. STREAMs indre loop er illustreret i hvert af out-of-class-felterne, og endelig er medtaget et felt til læringsmål, så planlægning af undervisningsaktiviteterne eksplicit holdes op mod de fastsatte mål.

For den almindelige underviser, som ikke er vant til at arbejde med out-ofclass-aktiviteter og ikke har erfaring med de værktøjer, som kan benyttes i aktiviteterne, kan det være en udfordring at tage en learning design-model i brug. Derfor er Health Learning Design Toolkit udvidet med værktøjer, der skal understøtte den systematiske brug i de faglige miljøer. Learning design-modellen er det centrale omdrejningspunkt i Health Learning Design Toolkit. For at understøtte modellen består toolkittet, inspireret af Dee Fink (Fink, 2005), desuden af en proces for udvikling af undervisningsforløb med handlingsorienterede trin (se tabel 1), som følges under udviklingen. Til hvert trin er knyttet en række udviklingsværktøjer som fx modeller, principper og guidelines, der understøtter udførelsen af det enkelte trin. Disse udviklingsværktøjer er en del af en dynamisk værktøjskasse, der kan opdateres løbende.

\begin{tabular}{|c|l|}
\hline Trin & Udviklingsværktøj \\
\hline 1. Identificér læringsmål & Learning design-model \\
\hline $\begin{array}{l}\text { 2. Planlæg sammenhængende } \\
\text { uddannelsesforløb }\end{array}$ & Learning design-model \\
\hline $\begin{array}{l}\text { 3. Planlæg aktiviteter } \\
\text { (content/activity) }\end{array}$ & $\begin{array}{l}\text { Papadopoulus: Script-principper } \\
\text { (Papadopoulus et al, 2013) }\end{array}$ \\
\hline 3.1. Planlæg specifik aktivitet & $\begin{array}{l}\text { Bower: The affordance analysis e-learning } \\
\text { design methodology (Bower, 2008) } \\
\text { Affordance-oversigt over centrale }\end{array}$ \\
\hline 3.2. Vælg læringsværktøjer & \\
\hline
\end{tabular}




\begin{tabular}{|l|l|}
\hline & læringsværktøjer \\
\hline 3.3. Lav aktivitet & $\begin{array}{l}\text { Mayer: Læringsprincipper for multimedie } \\
\text { Guidelines (Mayer, 2014) }\end{array}$ \\
\hline
\end{tabular}

Tabel 1. Procestrin for brug af Health Learning Design Model suppleret med angivelse af, hvilke dele af det samlede toolkit, der kan benyttes under udvikling af konkrete learning designs.

Overordnet set benytter HE og ST således samme learning designframework og systematik som basis for store dele af deres pædagogiske educational it-relaterede udviklingsarbejde og bidrager dermed til at skabe en fælles referenceramme på tværs af universitetet.

\section{Case 1: Uddannelse af undervisere på HE}

Udviklingen af learning design på HE er i høj grad sket i tilknytning til implementeringen af den nye e-læringsplatform og som følge af det øgede fokus på out-of-class-aktiviteter i den forbindelse. Derfor har undervisningen i brug af learning design hængt tæt sammen med undervisning i e-læringsplatformens konkrete funktionalitet.

Som følge af det pædagogiske centers ansvar for den organisatoriske og pædagogiske implementering, samt den tilknyttede uddannelse af underviserne, har implementeringsprojektet på Health vedtaget en uddannelsesplan for at sikre uddannelse til undervisere på alle kompetenceniveauer. Undervisningen til almene undervisere består af kurser i to niveauer: et basiskursus og et udvidet kursus. På basiskurset er fokus på forståelse af e-læringsplatformen og tryghed i brugen af basal funktionalitet for at føle sig hjemme i værktøjerne, inden man bevæger sig til de højere trin (Salmon, 2003). Underviseren bliver her inspireret og motiveret til at fortsætte med at understøtte og transformere (Puentedura, 2010) sin undervisning med educational it, når fortrolighed med de grundlæggende systemfunktioner er etableret. På det udvidede kursus for den almene underviser er det imidlertid både et ønske og en nødvendighed at flytte fokus fra system til den læring, som skal foregå ved hjælp af systemet, og til undervisningsudvikling understøttet af educational it.

Da learning design danner forbindelsen mellem teori og praksis ved at operationalisere teorien i praktisk anvendelige værktøjer (Conole et al., 2004), er det oplagt at bygge uddannelsen på e-læringsplatformen op over et learning design. Hermed tilbydes underviserne et redskab, der letter planlægningen af blendede undervisningsforløb og har til formål systematisk at eksplicitere og kvalitetssikre udviklingen af denne type forløb. Samtidig knyttes planlægningen sammen med praktisk brug af daglige redskaber i det system, hvor mange aktiviteter konkret vil foregå. 
Denne kobling af teori og praksis har betydning for transfer (Wahlgren, 2009), og learning design-modellen kan udvikle sig fra udelukkende at være et boundary object i kursussammenhænge til også at fungere i den konkrete anvendelse som en integreret del af undervisningsudviklingen i de faglige miljøer.

Kurset består konkret af to moduler, der hver introducerer en af de primære aspekter af out-of-class-loopet: Content og activity. Det ene modul indeholder lektioner, der omhandler indholdsudvikling, mens det andet består af lektioner om aktiverende undervisning. Modulerne er bundet sammen af en fælles lektion, som introducerer til HE's learning design (figur 4).

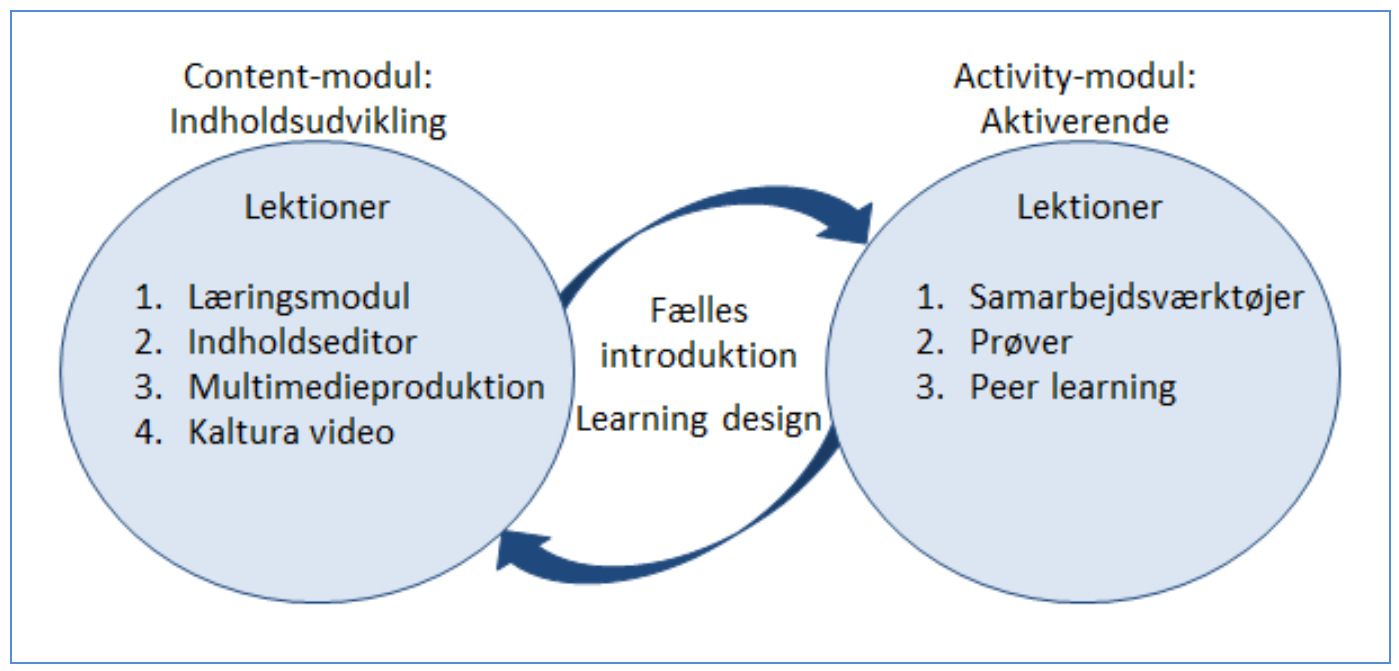

Figur 4. Sammenhæng mellem out-of-class-loop og lektioner i et udvidet Blackboard-kursus.

Health Learning Design Toolkit er ligeledes integreret med undervisningsprogrammet, således at den centrale model og processen med de trin, som gennemgås ved udvikling af et undervisningsforløb, præsenteres i den fælles introduktion. Udviklingsværktøjerne, som er knyttet til processens trin 1, 2, 3.1 og 3.2, præsenteres også i introduktionen, da dette omhandler planlægning generelt. I processens trin 3, Lav aktivitet, udvikles de enkelte aktiviteter i detaljer, hvilket er det centrale fokus i alle lektioner i både content- og activity-modulet. Her introduceres en række læringsværktøjer samt de udviklingsværktøjer og guidelines, som har betydning for udvikling af den specifikke aktivitet. Et eksempel er Indholdsudvikling - lektion 3, som omhandler multimedieproduktion. Her introduceres animations- og lydprogrammer sammen med Mayers læringsprincipper for multimedie (Mayer, 2014) og guidelines omkring fillængde, formater mv. Et andet eksempel er Aktiverende undervisning - lektion 1, som omhandler samarbejdsværktøjer. Her introduceres blogs, wikis og diskussionsfora, 
sammen med repetition og eksemplificering af Papadopoulus' Scriptprincipper (Papadopoulus et al, 2013) og guidelines for kommunikation.

Kurset er udviklet, så der veksles mellem oplæg og hands-on-opgaver (Herskin, 2000), hvilket giver mulighed for både at skabe overblik og forståelse af e-læringsplatformen sammen med praktisk erfaring med læringsværktøjer og et operationaliseret learning design.

Hvor basiskurset har kørt i et par år, er det udvidede kursus stadig i januar 2016 forholdsvist nyt. Men med udgangspunkt i erfaringerne fra basiskurserne både hvad angår deltagertal og interesse for udnyttelse af systemet til pædagogisk understøttelse af undervisningen, er der grundlag for at opnå flere fordele ved at samle undervisning i brug af learning design med konkret systemundervisning i en ny e-læringsplatform. For det første har en ny e-læringsplatform for flere undervisere betydet et øget fokus på educational it, og nye muligheder har givet et incitament for at ændre eller justere egen undervisning. Ydermere har kravet om brug af et nyt system og den medfølgende nødvendige fortrolighed med systemfunktionalitet fået mange undervisere til at opsøge de udbudte kurser (ca. 600 pr 1.1.16). Vi finder derfor, at det at introducere et learning design samtidig med en ny e-læringsplatform betyder, at det er nemmere at nå en bredere kreds af undervisere og dermed skabe et godt fundament for at udnytte learning design-modellens egenskaber for opskalering af systematisk planlagte undervisningsforløb. Samtidig gives undervisere på kurserne et fælles begrebsapparat og et boundary object i form af toolkit og model, der kan understøtte kommunikation omkring undervisningsplanlægning med kolleger og have betydning for skalérbarheden i de lokale miljøer.

Kobling af introduktion til learning design med implementering af en ny elæringsplatform betyder at der tidsmæssige kommer der en sammenhæng mellem teori og praksis, og desuden giver operationaliseringen af learning design-modellen og det medfølgende toolkit mulighed for direkte anvendelse i samspil med det øvrige kursusindhold. Forståelsen for brug af learning design og transfer fra undervisning til dagligt brug bliver derfor nemmere, og det bliver muligt at øge kvaliteten af konkrete undervisningsforløb med det samme.

At learning design-model og toolkit introduceres på et standardkursus har også betydning for omkostningerne. I modsætning til især boutique course development-tilgangen er det herved muligt at reducere den tid, som undervisere fra det pædagogiske center skal bruge på forberedelse. Der er flere kursister ad gangen, og efter få gange kan et kursus i introduktion til learning design og e-læringsplatform afholdes stort set uden forberedelse. Da kurserne endvidere er lektionsopdelte efter emner, er det muligt at afholde et standardkursus uden at gå på kompromis med relevans og målrettethed. Lektionerne fungerer som legoklodser, og det er muligt at 
afholde kurser målrettet bestemte faglige og funktionsspecifikke medarbejdergrupper.

Alt i alt har det haft positiv betydning for skalérbarheden at koble introduktion til learning design sammen med undervisning i en ny elæringsplatform. Man når bredt ud til mange undervisere, og synliggørelse af sammenhængen mellem teori og praksis, som kan give en umiddelbar kvalitetsforbedring af konkrete kurser, spredes tilsvarende uden store omkostninger.

\section{Case 2: Uddannelse af undervisere på ST}

Undervisere, der sigter mod en fastansættelse ved AU, skal på et tidspunkt gennemføre universitets adjunktpædagogikum (eller tilsvarende). Adjunktpædagogikum består af fire moduler af samlet set 5 ECTS, hvoraf det ene modul á 1 ECTS har temaet educational it og er tilrettelagt fakultetsvis. På ST har man valgt at lade learning design være det gennemgående tema for således at introducere underviserne til en systematisk metode til ibrugtagning af educational it i undervisningen samt give underviseren håndgribelige værktøjer til at udvikle sin undervisningspraksis.

Titlen på modulet er "Digital Learning Design", og det er tilrettelagt som godt fire ugers online undervisning baseret på STREAM vekslende mellem mindre pensumbidder og aktiviteter, og afrundet med en poster-session på universitetet (Godsk et al.; 2013). Hver uge er tilrettelagt som en læringssti med 6-12 trin og 4-7 aktiviteter. De fleste aktiviteter er obligatoriske, men, med undtagelse af to synkrone aktiviteter via videokonferencesystemet Adobe Connect, er alle aktiviteterne asynkrone og skal blot færdiggøres inden for de pågældende undervisningsuger. Figur 5 viser Uge 1's første trin samt en samlet oversigt over læringsstiens indhold. 


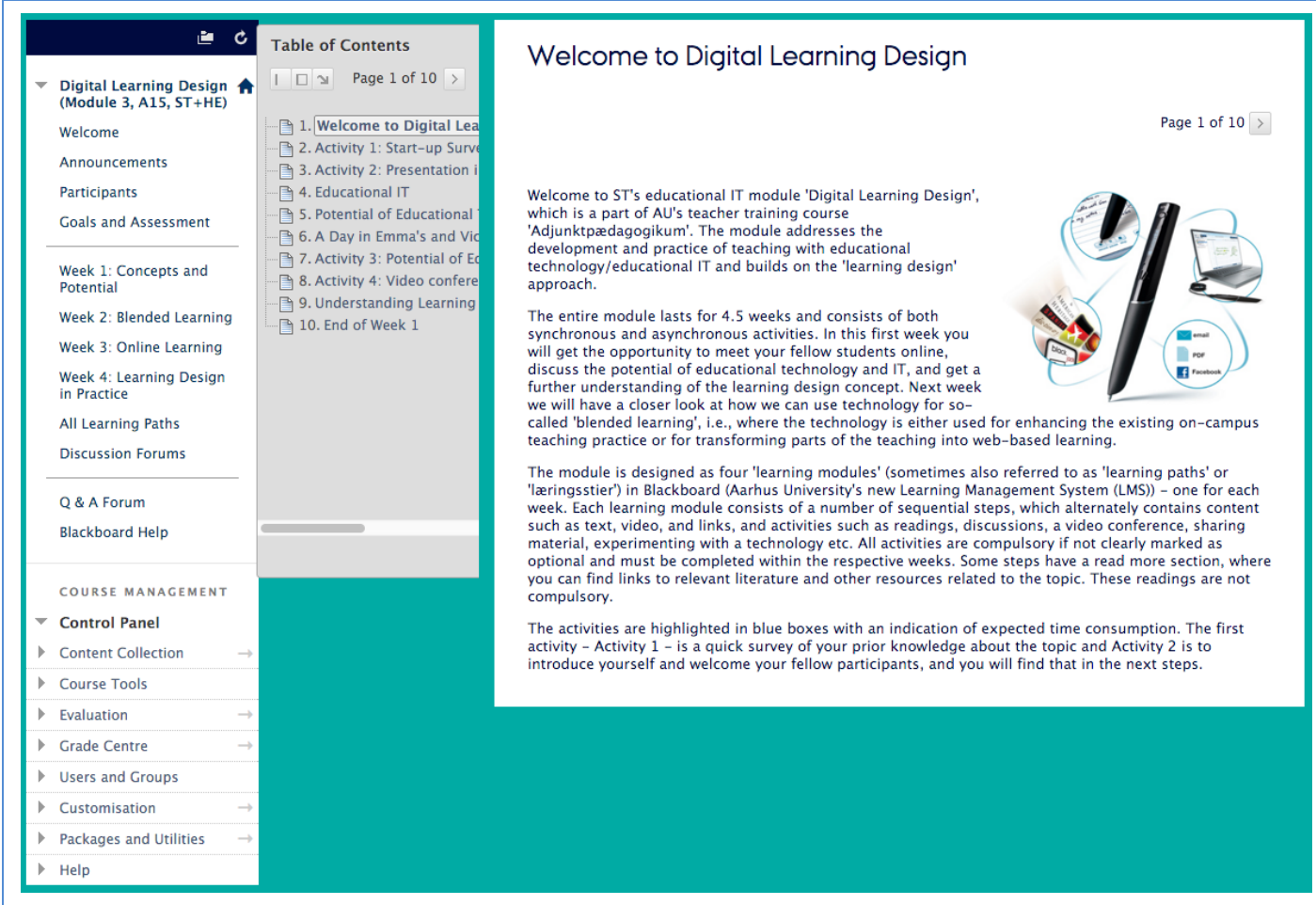

Figur 5. Trin 1, Uge 1 på Digital Learning Design implementeret som en læringssti i Blackboard.

På modulet introduceres learning design-begrebet og en række modeller, herunder STREAM, og deltagerne bliver bedt om at udvikle et learning design-koncept for deres egen undervisning. Det står deltagerne frit for, om de vil basere deres learning design på en eksisterende model eller udvikle deres egen, men erfaringerne viser, at $80 \%$ vælger at basere deres koncept på STREAM. Ydermere viser evalueringen af modulet, at $88 \%$ af deltagerne ser et potentiale for learning design til scienceundervisning, $80 \%$ har planer om at ibrugtage learning design i deres undervisning på sigt, og $45 \%$ har planer om ibrugtagning inden for det næste halve år (Bjælde et al., 2015).

Modulet tjener således både som en introduktion til og eksempel på learning design og den iboende systematik. Endvidere indeholder præsentationen af STREAM også en række begreber såsom feedback loop, out-of-class-aktiviteter, in-class-aktiviteter, som deltagerne kan benytte fremadrettet til at beskrive og dele deres pædagogiske idéer. I lyset af den høje interesse for ibrugtagning af learning design og dermed også tilgangens iboende potentialer for at øge undervisningskvaliteten, kan STREAM-initiativet således også på sigt fungere som en effektiv metode til udviklingen af undervisningen ved ST. 


\section{Case 3: Udvikling af undervisning på ST}

Foruden uddannelse af undervisere og implementering af ny elæringsplatform, har universitetet en ambitiøs målsætning om nytænkning af undervisningen vha. educational it. I lyset af de meget begrænsede ressourcer har ST valgt at fokusere på den undervisning og de undervisere, der har et særligt behov for at realisere teknologiens potentialer i undervisningen, er velvillige eller hvor indsatsen kan få en stor effekt. Udvælgelsen af undervisere og kurser er således ofte drevet af undervisernes eget ønske om at forbedre undervisningen, men der kan dog også ligge mere strategiske grunde bag. Eksempelvis har der ved Institut for Matematik været et særligt behov for at modernisere undervisningen, afskaffe forelæsninger og reducere underviserteamet på de tidskrævende kurser i calculus (Godsk, 2014a; 2014b).

Også til denne form for ad hoc-transformeringer anvender ST STREAM. Dette foregår ved, at underviseren almindeligvis retter henvendelse til fakultetets pædagogiske center, hvorefter der på baggrund af et kort møde med introduktion til STREAM-modellen aftales en plan for transformering af kurset og evt. produktion af materialer supporteret af SML. I modsætning til boutique course development-tilgangen, bliver der ikke udviklet et særligt pædagogisk koncept for det pågældende kursus, og det er oftest underviseren selv, der står for den egentlige transformering og materialeproduktion evt. supporteret af SML. Pædagogisk opfølgning og evaluering varetages af det pædagogiske center efter behov.

Foruden de direkte henvendelser bliver fakultetets undervisere introduceret til modellen ved forskellige lejligheder såsom workshops, konferencer, pædagogiske temamøder o lign. En akademisk artikel (Godsk, 2013), video og læringssti ligger frit tilgængeligt online, således underviserne selv kan opnå et basalt kendskab til STREAM. I skrivende stund har det pædagogiske center ved ST været direkte involveret i eller faciliteret transformeringen af de nedenstående 18 kurser samt dannet rammen for nytænkningen af en række adgangskurser, andre bachelor- og masterkurser, kursusmoduler og projektforløb til blended og online læring vha. modellen. Dertil kommer et ukendt antal transformeringer, hvor underviseren selv har stået for udviklingen. Tabel 2 viser en oversigt over de transformerede kurser inkl. graden af transformering og en opgørelse af deres effekt målt i ECTS. Transformeringsniveauerne augmentation og modification er varianter af blended learning, hvor teknologien henholdsvis forbedrer eksisterende undervisningspraksis og ændrer dele af undervisningen til online læring, mens redefinition her benytter transformeringer, hvor teknologien helt redefinerer undervisningsformen fx online learning (Godsk, 2014a; Puenteduras, 2010). 


\begin{tabular}{|c|c|c|}
\hline Kursus og ECTS-omfang & Niveau & Effekt og studerende \\
\hline Calculus 2 (2013), 5 ECTS & Modification & 3.550 ECTS $(n=710)^{*}$ \\
\hline Calculus 1 (2014), 5 ECTS & Modification & $5.240 \operatorname{ECTS}(\mathrm{n}=1.048)$ \\
\hline Calculus 2 (2014), 5 ECTS & Modification & 4.105 ECTS $(n=821)$ \\
\hline Calculus 1 (2015), 5 ECTS & Modification & $5.475 \operatorname{ECTS}(n=1.095)$ \\
\hline Calculus 2 (2015), 5 ECTS & Modification & $5.480 \operatorname{ECTS}(n=1.096)$ \\
\hline Astrofysik (2013), 5 ECTS & Augmentation & 615 ECTS $(n=123)$ \\
\hline Astrofysik (2014), 5 ECTS & Augmentation & $625 \operatorname{ECTS}(n=125)$ \\
\hline Astrofysik (2015), 5 ECTS & Augmentation & $735 \operatorname{ECTS}(\mathrm{n}=147)$ \\
\hline $\begin{array}{l}\text { Grundlæggende programmering }(2015)^{* *}, 5 \\
\text { ECTS }\end{array}$ & Redefinition & $205 \operatorname{ECTS}(n=41)$ \\
\hline Fysik $(2015)^{* *}, 5$ ECTS & Redefinition & $205 \operatorname{ECTS}(\mathrm{n}=41)$ \\
\hline Indledende digital elektronik $(2015)^{* *}, 5$ ECTS & Redefinition & $205 \operatorname{ECTS}(\mathrm{n}=41)$ \\
\hline Indledende kredsløbsteknik (2015)**, 5 ECTS & Redefinition & $205 \operatorname{ECTS}(\mathrm{n}=41)$ \\
\hline $\begin{array}{l}\text { Matematisk modellering af lineære systemer } \\
(2015)^{* *}, 5 \text { ECTS }\end{array}$ & Redefinition & $205 \operatorname{ECTS}(\mathrm{n}=41)$ \\
\hline Evolution og diversitet (2014), 5 ECTS & Augmentation & $615 \operatorname{ECTS}(n=123)$ \\
\hline Evolution og diversitet (2015), 5 ECTS & Augmentation & 585 ECTS $(n=117)$ \\
\hline Microbial Physiology (2014), 5 ECTS & Modification & $250 \operatorname{ECTS}(n=25)$ \\
\hline Microbial Physiology (2015), 5 ECTS & Modification & $120 \operatorname{ECTS}(n=12)$ \\
\hline Webteknologi (2016), 5 ECTS & Modification & $995 \operatorname{ECTS}(n=199)$ \\
\hline I alt & & $29.230 \operatorname{ECTS}(n=5.846)$ \\
\hline
\end{tabular}


Tabel 2. Effekt af STREAM målt i kurser, transformeringsniveau, ECTS og antal studerende (se også Bjælde et al., 2015). *Antallet af studerende er beregnet, da $40 \%$ af holdet fulgte et traditionelt forløb. ${ }^{* *}$ Disse kurser er en del af samme uddannelse. Der tages forbehold for frafald af studerende, som ikke fremgik af kursernes deltagerlister.

Som tidligere beskrevet er STREAM ikke en detaljeret drejebog for transformeringen af kurser, og der er således variation i de implementerede designs. Calculus 1 og 2 er eksempler på kurser, der følger STREAM forholdsvis stringent. Figur 6 illustrerer learning designet for Calculus 1, 2015, herunder dets brug af læringsstier med et out-of-classloop, refleksionsøvelser til in-class og online feedback (vha. en $e$-instruktor) samt supportfora.

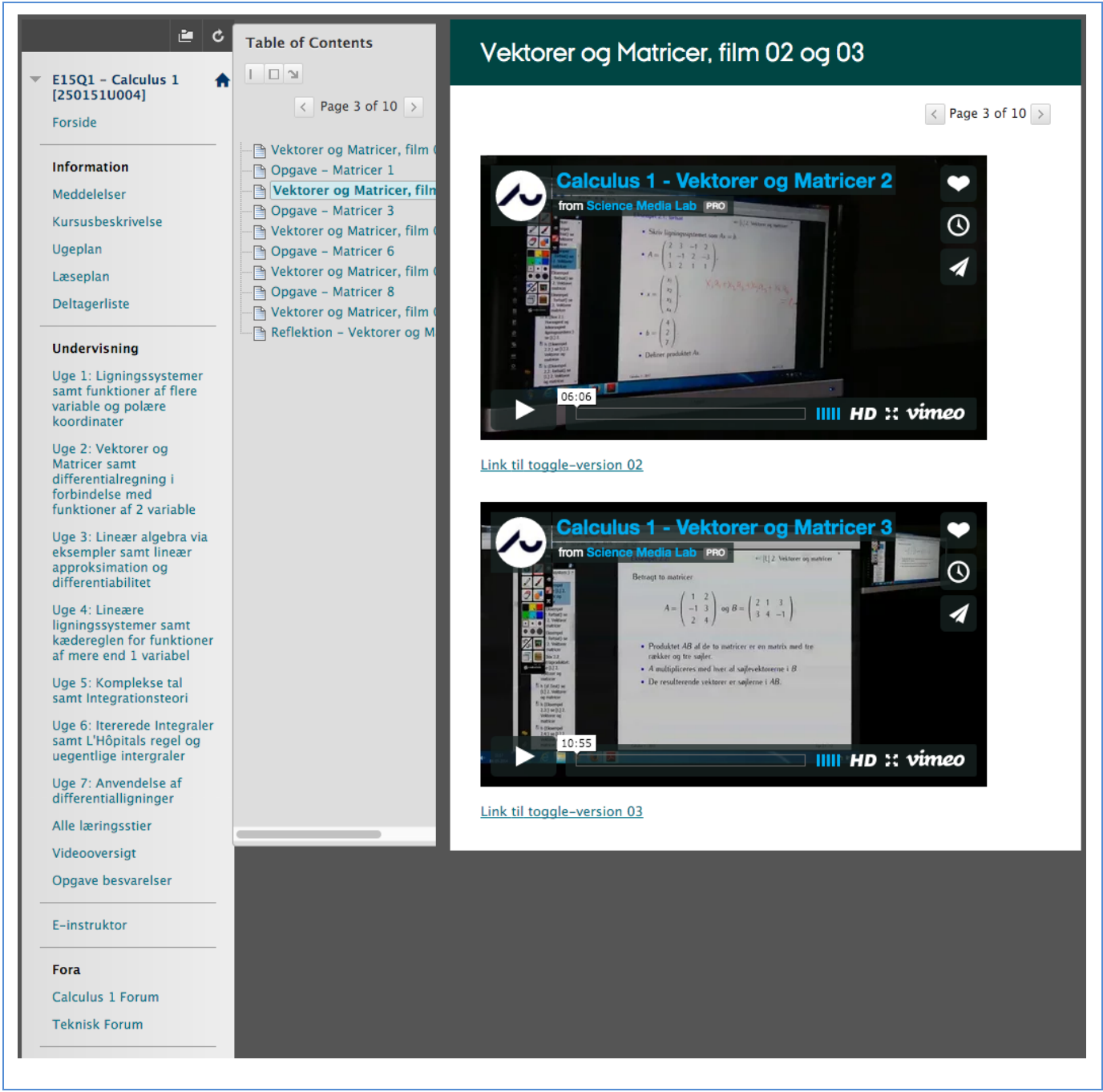

Figur 6: Calculus 1 (2015) som eksempel på et STREAM-transformeret kursus.

Afhængigt af den ønskede undervisningsform og underviserens præferencer kan transformeringen baseres på såvel eksisterende materialer og lærebøger som nyudviklede undervisningsmaterialer. 
Erfaringerne fra de første transformeringer viser, at en del undervisere foretrækker egenproducerede videoer til at formidle pensum og evt. til at give feedback ( $13 \mathrm{ud}$ af 18 kurser i Tabel 2 benytter egenproducerede videoer). En vigtig del af ST's toolkit er derfor de føromtalte webcaststudier, hvor underviseren selv producerer sine materialer. Tabel 2 illustrerer ligeledes en vis grad af bæredygtighed af tilgangen, da underviserne og/eller kurserne ofte fortsætter med den transformerede undervisningsform. I praksis betyder undervisernes egen udvikling af undervisningen og evt. fortsatte anvendelse af STREAM, at rollen for det pædagogiske center minimeres, og at der frigøres ressourcer til transformering af endnu flere kurser. Ydermere har en række målinger vist, at tilfredsheden, fleksibiliteten og/eller eksamensresultaterne er blevet forbedret på de transformerede kurser (Bjælde et al., 2015; Godsk, 2014a; 2014b)

\section{Konklusion}

Både lone ranger- og boutique course development-tilgangene har deres fordele og kan være nyttige til bl.a. at demonstrere potentialerne ved educational it og at sikre en høj pædagogisk kvalitet på et specifikt kursus. Det kan imidlertid være vanskeligt at overføre erfaringerne, da løsningerne er skræddersyede til bestemte kurser og afhængige af bestemte undervisere, hvilket giver en reel risiko for, at det pågældende design ikke genbruges og således bliver et one-hit wonder. Netop af den årsag er learning design-tilgangen og erfaringerne fra HE og ST med introduktionen af STREAM og operationaliseringen heraf interessante.

Samlet set ser det ud til, at learning design, koblet med et undervisningsudviklingsinitiativ og et uddannelsesinitiativ, har gjort det muligt at systematisere introduktion til en e-læringsplatform, uddannelse af undervisere samt transformering ("nytænkning") af undervisning på HE og ST. Evalueringerne fra ST viser, at underviserne finder learning design og STREAM nyttige og relevante for udviklingen af deres undervisning, og hele $80 \%$ forventer at gøre brug af learning design i deres undervisning. Endvidere viser målinger, at tilfredsheden, fleksibiliteten og/eller eksamensresultaterne er blevet forbedret på de transformerede kurser. På HE er de foreløbige erfaringer, at det udbyttet ved at indføre learning design øges ved at koble undervisningen i emnet med undervisningen i den ny e-læringsplatform. Dels pga. den voksende mængde af undervisere, der opsøger kurserne, også betyder et øget kendskab til learning design og toolkit, dels også fordi sammenhængen mellem teori og praksis bliver tydelig for underviserne, der kan bruge den operationaliserede model direkte i sammenhæng med det øvrige kursusindhold. Brugen af learning design făr derfor bedre mulighed for at blive integreret i den praktiske udvikling af undervisningsforløb. 
Det er endnu ikke muligt at sige noget om den samlede effektivitet, som følger af learning design-tilgangen på AU, men i skrivende stund er der ved at blive udviklet en metode til at måle effektiviteten af transformeringer baseret på interesser, indsats og effekt, som vil blive taget i brug til identificering og analyse af faktorer for effektiv undervisningsudvikling vha. learning design (Godsk, 2016). Alene systematikken forbundet med anvendelsen af modeller baseret på samme begrebsapparat suppleret med toolkits, den kvalitetssikring en underliggende og pædagogisk velfunderet model fordrer samt underviserens aktive rolle som udvikler af egen undervisning vha. educational it er dog med til at skabe en mere skalérbar og bæredygtig tilgang og fundament for implementering af educational it uden lone ranger- og boutique course development-tilgangenes iboende begrænsninger.

Endvidere har det vist sig muligt at bruge learning design-konceptet og modeller baseret på STREAMs begrebsapparat som tilbagevendende ramme for både undervisningsudvikling, kursus- og workshopaktiviteter og ad hoc-transformering af kurser vha. teknologi. Dette har medført, at mange undervisere nu taler samme sprog, og at det er muligt at give feedback på hinandens learning design vha. learning design-modellen. Desuden bliver det muligt at evaluere effekt på undervisningen og således arbejde med evidens, hvilket har en potentiel stor indflydelse på undervisere og deres ibrugtagning af educational it $\mathrm{i}$ et forskningstungt miljø.

Alt i alt betyder en systematisk tilgang til undervisningsudvikling og et fælles begrebsapparat, at ingen behøver at genopfinde hjulet og skabe endnu et one-hit wonder, når det både er nemt og bekvemt at tilrettelægge undervisning af høj kvalitet vha. gennemprøvede modeller. Det er således planen at fortsætte den videre udvikling og udbredelse af learning design ved HE og ST til uddannelse af undervisere og udvikling af undervisning samt ultimativt bryde the iron triangle vha. educational it.

\section{Referencer}

Agostinho, S. (2006). The use of a visual learning design representation to document and communicate teaching ideas. Proceedings of the 23rd annual ascilite conference: Who's learning? Whose technology? Retrieved June 4, 2014, from http://www.ascilite.org.au/conferences/sydney06/proceeding/pdf_pap ers/p173.pdf.

Bates, A. T. (2005). Technology, e-learning and distance education. Routledge.

Biggs, J. \& Tang, C. (2011). Teaching for Quality Learning at University (4th Edition). Berkshire: McGraw-Hill. 
Bjælde, O.E., Caspersen, M.E., Godsk, M., Hougaard, R.F., \& Lindberg, A.B. (2015). Learning design for science teacher training and educational development. In T. Reiners, B.R. von Konsky, D.Gibson, V. Chang, L. Irving, \& K. Clarke (Eds.), Globally connected, digitally enabled. Proceedings ascilite 2015.

Bloom, B. S. (1956). Taxonomy of educational objectives. Vol. 1: Cognitive domain. New York: McKay, 20-24.

Bonwell, C. C., \& Eison, J. A. (1991). Active learning: Creating excitement in the classroom. Washington, DC: School of Education and Human Development, George Washington University.

Bower, M. (2008). Affordance analysis - matching learning tasks with learning technologies. In Educational Media International Vol. 45, No. 1, March 2008, 3-15. Retrieved from http://dx.doi.org/10.1080/09523980701847115.

Britain, S. (2004). A review of learning design: concept, specifications and tools. A report for the JISC E-learning Pedagogy Programme, 2006.

Conole, G. (2013). Designing for learning in an open world. Springer.

Conole, G., Dyke, M., Oliver, M., \& Seale, J. (2004). Mapping pedagogy and tools for effective learning design. Computers \& Education, 43(1), 17-33.

Conole, G., \& Fill, K. (2005). A learning design toolkit to create pedagogically effective learning activities. Journal of Interactive Media in Education, 2005(1).

Conole, G., \& Oliver, M. (2002). Embedding theory into learning technology practice with toolkits. Journal of Interactive Media in Education, 2002(1).

Cross, S., \& Conole, G. (2009). Learn about learning design. Part of the OU Learn about series of guides, The Open University: Milton Keynes. Retrieved November 21, 2013, from http://www.open.ac.uk/blogs/OULDI/wpcontent/uploads/2010/11/Learn-about-learning-design_v7.doc.

Cross, S., Conole, G., Clark, P., Brasher, A., \& Weller, M. (2008). Mapping a landscape of Learning Design: identifying key trends in current practice at the Open University. In: 2008

European LAMS Conference, 25-27 June 2008, Cadiz, Spain. Retrieved June 4, 2014, from http://oro.open.ac.uk/18640/5/CAD08_022_Final.pdf.

Daniel, J., Kanwar, A., \& Uvalić-Trumbić, S. (2009). Breaking higher education's iron triangle: Access, cost, and quality. Change: The Magazine of Higher Learning, 41(2), 30-35.

Denny, P., Hamer, J., Luxton-Reilly, A., \& Purchase, H. (2008a). PeerWise: students sharing their multiple choice questions. In Proceedings of the Fourth international Workshop on Computing Education Research (pp. 51-58). ACM. 
Denny, P., Luxton-Reilly, A., \& Hamer, J. (2008b). The PeerWise system of student contributed assessment questions. In Proceedings of the tenth conference on Australasian computing education-Volume 78 (pp. 69-74). Australian Computer Society, Inc.

Fill, K. (2005). A learning design toolkit to create pedagogically effective learning activities. Journal of Interactive Media in Education, 2005(1).

Finansministeriet (2016). Aftale mellem regeringen, Dansk Folkeparti, Liberal Alliance og Det Konservative Folkeparti: Finansloven for 2016 (19. november 2015). Retrieved from http://www.fm.dk/ /media/files/nyheder/pressemeddelelser/2015/ 11/aftale-om-finansloven-for-2016.ashx

Fink, L. D. (2013). Creating Significant Learning Experiences: An Integrated Approach to Designing Collage Courses (2nd Edition). San Francisco: John Wiley \& Sons.

Fink, L. D. (2005). IDEA Paper \#42: Integrated Course Design. Manhattan, Kansas: The IDEA Center. Retrieved from http://ideaedu.org/wpcontent/uploads/2014/11/Idea_Paper_42.pdf.

Godsk, M. (2013). STREAM: a Flexible Model for Transforming Higher Science Education into Blended and Online Learning. In T. Bastiaens \& G. Marks (Eds.), Proceedings of E-learn 2013. Chesapeake, VA: AACE, 722728.

Godsk, M. (2014a). Efficient learning design - concept, catalyst, and cases. In B. Hegarty, J. McDonald, \& S.-K. Loke (Eds.), Rhetoric and Reality: Critical perspectives on educational technology. Proceedings ascilite Dunedin 2014, 182-189.

Godsk, M. (2014b). Improving Learning in a Traditional, Large-Scale Science Module with a Simple and Efficient Learning Design. European Journal of Open, Distance and E-Learning, 17 (2), 143-159.

Godsk, M. (2016). Learning Design for Efficient Educational Development: Conceptualisation and Assessment. Designs for Learning 2016, Copenhagen, Denmark.

Herskin, B. (2000). IT-undervisning - med brugeren i centrum. København: Teknisk Forlag.

Koper, R., \& Tattersall, C. (Eds.) (2010). Learning Design. A Handbook on Modelling and Delivering Networked Education and Training. Springer.

LifeSize (2016). Video Conference Streaming \& Recording | Lifesize UVC Video Center. https://www.lifesize.com/en/products/videoconferencing-infrastructure/video-streaming-and-recording.

Mayer, R.E. (2014). Research-Based Principles for Designing Multimedia Instructions. In V. A. Benassi, C. E. Overson, C. M. Hakala (Eds.), Applying Science of Learning in Education: Infusing Psychological Science into the Curriculum (pp. 59-70). Retrieved from the Society for the Teaching of 
Psychology web site:

http://teachpsych.org/ebooks/asle2014/index.php.

Mazur, E., \& Hilborn, R. C. (1997). Peer instruction: A user's manual. Physics Today, 50(4), 68-69.

Mor, Y., \& Craft, B. (2012). Learning design: reflections upon the current landscape. Research in learning technology, 20.

Mor, Y., \& Winters, N. (2007). Design approaches in technology-enhanced learning. Interactive Learning Environments, 15(1), 61-75.

Novak, G. M., Patterson, E. T., Gavrin, A. D., \& Christian, W. (1999). Just-inTime Teaching: Blending Active Learning with Web Technology. Upper Saddle River, NJ: Prentice Hall.

Oliver, M., \& Conole, G. (2000). Assessing and enhancing quality using toolkits. Quality Assurance in Education, 8(1), 32-37.

Papadopoulos, P. M., Demetriadis, S.N., Weinberger, A. (2013). 'Make it explicit!' : Improving collaboration through increase of script coercion. In Journal of Computer Assisted Learning, Vol. 29, Nr. 4, 2013, s. 383398. Retrieved from http://onlinelibrary.wiley.com/doi/10.1111/jcal.12014/abstract.

Puentedura, R. (2010). SAMR and TPCK: Intro to Advanced Practice. http://hippasus.com/resources/sweden2010/SAMR_TPCK_IntroToAdv ancedPractice.pdf.

Simkins, S. P., \& Maier, M. H. (2010). Editors' Preface. Just-in-Time Teaching: Across the Disciplines, and Across the Academy.

Sims, R. (2006). Beyond instructional design: Making learning design a reality. Journal of Learning Design, 1(2), 1-7. Retrieved from https://www.jld.edu.au/article/download/11/8.

Star, S. L., \& Griesemer, J. R. (1989). Institutional ecology,translations' and boundary objects: Amateurs and professionals in Berkeley's Museum of Vertebrate Zoology, 1907-39. Social studies of science, 19(3), 387-420.

Uddannelses- og forskningsministeriet (2014). Reform af SU-systemet og rammerne for studiegennemførelse - Uddannelses- og Forskningsministeriet. Retrieved from http://ufm.dk/lovstof/politiskeaftaler/reform-af-su-systemet-og-rammerne-for-studiegennemforelse.

Wahlgren, B. (2009). Transfer mellem uddannelse og arbejde. København: Danmarks Pædagogiske Universitetsskole, Aarhus Universitet, Nationalt center for kompetenceudvikling. Retrieved from http://edu.au.dk/aktuelt/aktuelle-temaer/transfer.

Wenger, E. (2000). Communities of practice and social learning systems. Organization, 7(2), 225-246.

Aarhus Universitet (2011). Den Faglige Udviklingsproces. Øvrige bilag. Universitetsledelsen den. 9. marts. Retrieved May 1, 2016, from 
http://medarbejdere.au.dk/fileadmin/res/fau/dok/fau_bilag_oevrige_b ilag_090311.pdf. 